\title{
Press and Political Polarization of Nigerian National Development
}

\author{
Obiora, Anichebe, Ph.D. \\ Humanities Unit, School of General Studies, University of Nigeria, Enugu Campus \\ Onwuama, Emeka Michael, Ph.D \\ Humanities Unit, School of General Studies, University of Nigeria, Enugu Campus
}

\begin{abstract}
The study was to evaluate the press and the political polarization of Nigeria National Development. The specific objectives were to: examine the extent the Nigerian newspapers' headline has affected the provision of unified quality education and skill development in Nigeria, evaluate the relationship between media contact and programmatic safety and security in Nigeria and determine the relationship between contact information and provision of employment in Nigeria. The total population for the study was four thousand, seven hundred and twenty six $(4,726)$ comprising civil servants, business men and women in Enugu metropolis. The study used the survey approach. The primary sources were personal interview and the administration of questionnaire to the traders. Out of a population of 4726 traders, the sample size of 472.6 was chosen after applying the 10 percent of the total population for the determination of adequate sample size. Out of 473 respondents of the sample size, 373 respondents returned the questionnaire and accurately filled. Z-test, Pearson correlation coefficient, (F-statistics), and regression analysis were used to test the hypotheses, determine the nature, and strength of the research variables. The findings indicated that Nigerian newspapers' headline has positive effect on the provision of unified quality education and skill development in Nigeria to an extent with $Z(95, \mathrm{n}=373)=5.380, \mathrm{p}>0.05$, Media contact and programmatic safety and security in Nigeria are significantly related with $Z(95, \mathrm{n}=373)=5.267, \mathrm{p}>$ 0.05 and Contact information and provision of employment in Nigeria are significantly related with Z $(95, \mathrm{n}=373)$ $=5.88, \mathrm{p}>0.05$. The study concluded that there is a relationship between media contact, contact information and provision of employment, programmatic safety and security and that the Nigerian newspapers' headlines has affect on the provision of unified quality education and skill development in Nigeria. The study recommended that the Nigerian newspapers' headline should be guided properly to avoid jeopardizing with the intellectual acquisition of the people.
\end{abstract}

Keywords: Press, Political Polarization of Nigeria National Development, Nigerian newspapers' headline, Unified quality education, Skill development, Media contact etc.

DOI: $10.7176 / \mathrm{JLPG} / 96-10$

Publication date: April $30^{\text {th }} 2020$

\subsection{Introduction}

The kind of influence that the press and mass media wield over the electorate and general public in any country is usually huge. And in the light of recent developments and political clamor, news reporting in Nigeria has really improved, especially with the introduction of online reporting. Kadiri et al. (2015) noted that the press are the chief suppliers of information from which the masses make judgments. This means that the press are at a strategic position to promote as well as discourage popular opinions. The Oxford Dictionary (2010) defines mass media as a diverse array of media technologies that reach a large audience via mass communication. The technologies through which this communication takes place include a variety of outlets. This shows that the press constitute the agents or personnel of mass media.

However, the diversity in Nigeria with regards to ethnic groups and large population, and the press has played a role, somewhat, on the political polarization in Nigeria. Baldasarri and Gelman (2008) sees polarization as a divide among the electorates across party lines. This means that political polarization has the masses actively supporting their parties of interest, sometimes even at the cost of national development. There is also the case of elite polarization in which political parties, the one in power and the opposition are clearly antagonizing each other. This is evident in the case of All Progressive Congress and Peoples' Democratic Party in Nigeria.

Furthermore, national development has been a topic on the lips of all and sunder since Nigeria got her independence. Lawal and Oluwatoyin (2011) identified national development as a collection of strategic plans mapped out by the government towards development. However, it is noteworthy that national development is better achieved under a united front. The issue of political polarization makes it harder for the government and masses alike to pull together in matters of national interest. Nigeria as a country has embarked on various national development plans ranging from the $1^{\text {st }}$ national development plan to the $5^{\text {th }}$. Various governments have also embarked on projects in attempts to address national development in Nigeria properly. However, till national unity is promoted, it would be hard to achieve national development in Nigeria in the face of political polarization engineered by the press. 


\subsection{Statement of the Problem}

Nigeria is a country blessed with numerous ethnic groups, each having its own unique characteristics. During the struggle for independence, one of the factors that granted victory for Nigeria was the unity in public opinion on the ills of colonialism. There was a sort of togetherness towards a single course shown by all tribes. Even in the years that followed, she experienced prosperity due to the nationalistic spirits fostered by early political fathers. Even journalism was quality and was highly regarded.

However, after the 1966 coup, everything shattered, and everyone went to their tents. Henceforth, there was a quick split in public opinion as each group seemed to speak in their own favour. The press became bias and tend to say anything to favor the agenda of the controlling few. This has risen to the extent that even in matters of national importance, there does not seem to be a singular opinion on the part of Nigerians. There seem to be extreme views regarding issues in Nigeria, with each group favoring their tribes. In as much as this is a normal human behaviour, it is important that it is minimized and not used by people as means of antagonizing one another or being tribalistic. This is mostly seen in political allegiances to parties, which each faction of the public favouring a particular political party in Nigeria. The level of polarization has resulted in two major political parties in Nigeria with each at the others throat on matters of national interest.

Political polarization has obviously affected provision of quality education in Nigeria, impacted on issues of safety and security in Nigeria, as well as reducing employment opportunities in Nigeria. In a bid to supporting various ideas based on political alignments, there is the tendency that the masses may play themselves, and jeopardize issues in the interest of national development like the provision of quality education. The press through newspaper headlines have sometimes fostered agenda that polarized the masses, thereby negatively impacting on the provision of unified quality education and skill development in Nigeria. This same issue has also trickled down to the provision of employment and safety and security in Nigeria, hence the study aims to evaluate the press and political polarization of Nigeria National Development.

\subsection{Objectives of the Study}

The main objective of the study was to evaluate the press and the political polarization of Nigeria National Development. The specific objectives were to;

i. Examine the extent the Nigerian newspapers' headlines has affected the provision of unified quality education and skill development in Nigeria.

ii. Evaluate the relationship between media contact and programmatic safety and security in Nigeria.

iii. Determine the relationship between contact information and provision of employment in Nigeria.

\subsection{Research Questions}

The following research questions guided the study;

i. To what extent does the Nigerian newspapers' headline affect the provision of unified quality education and skill development?

ii. What is the relationship between media contact and programmatic and security in Nigeria?

iii. What is the relationship between contact information and provision of employment in Nigeria?

\subsection{Statement of Hypotheses}

The following alternate hypotheses guided the study;

i. Nigerian newspapers' headline has positive effect on the provision of unified quality education and skill development in Nigeria to an extent.

ii. Media contact and programmatic safety and security in Nigeria are significantly related.

iii. Contact information and provision of employment in Nigeria are significantly related.

\subsection{Significance of the Study}

The study will be of significance to the government and policy makers in their bid to promote national unity in Nigeria, as well as properly harnessing its diverse features. Also, future researchers will also benefit from this work by making it as a reference point in further researches.

\section{REVIEW OF RELATED LITERATURE}

\subsection{Conceptual Framework}

\subsubsection{The Press}

The Merriam-Webster Dictionary (2019) defies the press as people such as reporters and photographers who work for newspapers and magazines. The press could also be used synonymously with mass media. The press has the role of providing information and reports to the general public in countries like Nigeria. It is usually the information that the press provide that gets published in the media. The role of mass media for sustainable democracy cannot be overemphasized. Although, the primary responsibilities of the media is to entertain without slander or libel, 
inform based on accurate facts and educate on current relevant issues. The mass media are supplying the political information that voters base their decision on. They identify problems in the society and serve as a medium for deliberation (Kadiri, 2015).

The mass media constitute the brain box of democracy. The media help in the supply of the required political information that electorates would base their decision. They are the watchdogs for uncovering errors and wrongdoing by those in power (Fog, 2004; Kellner 2004). Also, there have been instances of wrong and erroneous reporting on the part of the press and media, and the kind of followship that they attract means that they have a lot of influence on people.

\subsubsection{Political Polarization}

In politics, polarization (or polarisation) can refer to the divergence of political attitudes to ideological extremes. Almost all discussions of polarization in political science consider polarization in the context of political parties and democratic systems of government. In most two-party systems, political polarization embodies the tension of its binary political ideologies and partisan identities (DiMargio, Evans and Brighton, 1996)

According to DiMaggio et al. (1996), "Polarization is both a state and a process. Polarization as a state refers to the extent to which opinions on an issue are opposed in relation to some theoretical maximum. Polarization as a process refers to the increase in such opposition over time". Polarization can be benign, natural, and democratizing, or it can be pernicious, having longterm malignant effects on society and congesting essential democratic functions (Varieties of Democracy Report, 2019). Some political scientists argue that polarization requires divergence on a broad range of issues, while others argue that only a few issues are required (Bafumi $\&$ Shapiro, 2009)

Political scientists typically distinguish between two levels of political polarization: elite and mass. "Elite polarization" focuses on the polarization of the political elites, like party organizers and elected officials. "Mass polarization" (or popular polarization) focuses on the polarization of the masses, most often the electorate or general public. Conventionally, political polarization is viewed in terms of issue positions or policy attitudes, including ideological distance between elites (political parties, party manifestos, or legislative voting) or the masses (voters self-sorting into increasingly homogenous political parties or self-placement on ideological scales). Some political scientists assert that contemporary polarization depends less on policy differences on a left and right scale, but increasingly on other divisions such as: religious against secular; nationalist against globalist; traditional against modern; rural against urban.

\subsubsection{Nigeria National Development}

National, according to Longman dictionary of contemporary English, refers to a phenomenon that embraces a whole nation. National development therefore can be described as the overall development or a collective socioeconomic, political as well as religious advancement of a country or nation. This is best achieved through development planning, which can be described as the country's collection of strategies mapped out by the government (Lawal and Oluwatoyin, 2011).

A country is said to be developed if it is able to provide qualitative life for her citizenry. In this regard, Nigeria, through various governments, has embarked upon numerous development policies, plans, programmes and projects, in her quest to improve the material well being and welfare of the citizens. According to Sanusi (2012), the following are some of the notable developmental efforts of various governments in Nigeria since independence: (i) First National Development Plan (1962-1968); (ii) Second National Development Plan (1970-1974); (iii) Third National Development Plan (1975-1980); (iv) Fourth National Development Plan (1981-1985); (v) Structural Adjustment Programme; (vi) Vision 2010; (vii) National Economic Empowerment and Development Strategy (NEEDS); (viii) Vision 2020; and a host of others.

\subsubsection{Unified Quality Education}

Quality as contained in Oxford Advanced Learner's Dictionary (2010), means the standard of something when it is compared to other things like it; how good or bad something is. Quality is used on every commodity e.g quality shoes, shirts, cars, etc. When a woman selling banana in the market sees a potential customer approaching her shed, she will not waste time to make use of "quality" to draw the man nearer for the purchase of her banana. Thus she will say "buy high quality banana". This means that any commodity can either be of a high quality or low quality. Equally we have low quality and high quality education.

Having seen what quality stands for, let us now briefly define education before marrying the two words - for a better understanding of the concept "Quality education" Today, education has become one of the greatest enterprises and has been defined in different ways by different people in different parts of the world and occupations. Education could be seen as the transmission of what is worthwhile to those who are committed to it - be they children or adults. Features that make up quality education include, quality learners, quality learning environment and quality content (Eze, 2009)

\subsubsection{Skill Development}

A skill is the ability to carry out a task with determined results often within a given amount of time, energy, or both. Skills can often be divided into domain-general and domain-specific skills. For example, in the domain of 
work, some general skills would include time management, teamwork and leadership, self-motivation and others, whereas domain-specific skills would be used only for a certain job. Skill usually requires certain environmental stimuli and situations to assess the level of skill being shown and used (Rao, 2010).

Skills development is the process of identifying your skill gaps, and developing and honing these skills. It is important because your skills determine your ability to execute your plans with success. Business dictionary defines it as An ability and capacity acquired through deliberate, systematic, and sustained effort to smoothly and adaptively carryout complex activities or job functions involving ideas (cognitive skills), things (technical skills), and/or people (interpersonal skills).

\subsection{Theoretical Framework}

\subsubsection{Uses and Gratifications Theory}

Uses and gratifications theory (UGTtheory) is an approach to understanding why and how people actively seek out specific media to satisfy specific needs. UGT is an audience-centered approach to understanding mass communication. Diverging from other media effect theories that question "what does media do to people?", UGT focuses on "what do people do with media? It postulates that media is a highly available product and the audiences are the consumers of the same product (Severin and Tankard, 1997).

This communication theory is positivistic in its approach, based in the socio-psychological communication tradition, and focuses on communication at the mass media scale. The driving question of UGT is: Why do people use media and what do they use them for? UGT discusses how users deliberately choose media that will satisfy given needs and allow one to enhance knowledge, relaxation, social interactions/companionship, diversion, or escape (McQuail, 2010).

It assumes that audience members are not passive consumers of media. Rather, the audience has power over their media consumption and assumes an active role in interpreting and integrating media into their own lives. Unlike other theoretical perspectives, UGT holds that audiences are responsible for choosing media to meet their desires and needs to achieve gratification. This theory would then imply that the media compete against other information sources for viewers' gratification. UGT has a heuristic value today because it gives communication scholars a "perspective through which a number of ideas and theories about media choice, consumption, and even impact can be viewed (Baran and Davis, 2009).

\subsubsection{Assumptions of the theory}

Unlike other theories concerning media consumption, UGT gives the consumer power to discern what media they consume, with the assumption that the consumer has a clear intent and use. This contradicts previous theories such as mass society theory, that states that people are helpless victims of mass media produced by large companies; and individual differences perspective, which states that intelligence and self-esteem largely drive an individual's media choice (Gusfield, 1994).

Given these differing theories, UGT is unique in its assumptions:

- The audience is active and its media use is goal oriented

- The initiative in linking need gratification to a specific medium choice rests with the audience member

- The media compete with other resources for need satisfaction

- People have enough self-awareness of their media use, interests, and motives to be able to provide researchers with an accurate picture of that use.

- Value judgments of media content can only be assessed by the audience.

\subsubsection{Social Cognitive Theory}

Social cognitive theory (SCT), used in psychology, education, and communication, holds that portions of an individual's knowledge acquisition can be directly related to observing others within the context of social interactions, experiences, and outside media influences. This theory was advanced by Albert Bandura (1994) as an extension of his social learning theory. The theory states that when people observe a model performing a behavior and the consequences of that behavior, they remember the sequence of events and use this information to guide subsequent behaviors. Observing a model can also prompt the viewer to engage in behavior they already learned. In other words, people do not learn new behaviors solely by trying them and either succeeding or failing, but rather, the survival of humanity is dependent upon the replication of the actions of others. Depending on whether people are rewarded or punished for their behavior and the outcome of the behavior, the observer may choose to replicate behavior modeled. Media provides models for a vast array of people in many different environmental settings.

Social cognitive theory is a learning theory based on the idea that people learn by observing others. These learned behaviors can be central to one's personality. While social psychologists agree that the environment one grows up in contributes to behavior, the individual person (and therefore cognition) is just as important. People learn by observing others, with the environment, behavior, and cognition acting as primary factors that influence development in a reciprocal triadic relationship. Each behavior witnessed can change a person's way of thinking (cognition). Similarly, the environment one is raised in may influence later behaviors. For example, a caregiver's 
mindset (also cognition) determines the environment in which their children are raised.

The core concepts of this theory are explained by Bandura (1994) through a schematization of triadic reciprocal causation, The schema shows how the reproduction of an observed behavior is influenced by the interaction of the following three determinants:

1. Personal: Whether the individual has high or low self-efficacy toward the behavior (i.e. Get the learner to believe in his or her personal abilities to correctly complete a behavior).

2. Behavioral: The response an individual receives after they perform a behavior (i.e. Provide chances for the learner to experience successful learning as a result of performing the behavior correctly).

3. Environmental: Aspects of the environment or setting that influence the individual's ability to successfully complete a behavior (i.e. Make environmental conditions conducive for improved self-efficacy by providing appropriate support and materials).

It is important to note that learning can occur without a change in behavior. According to J.E. Ormrod's general principles of social learning, while a visible change in behavior is the most common proof of learning, it is not absolutely necessary. Social learning theorists believe that because people can learn through observation alone, their learning may not necessarily be shown in their performance. These are interdependent on each other and its influence can be directly linked with individual or group psychological behavior. According to Stajkovic and Luthans (2003), it is critically important to recognize that the relative influences exerted by one, two, or three interacting factors on motivated behavior will vary depending on different activities, different individuals and different circumstances.

\subsection{Empirical Review}

Aleyomi, Ajakaiye, Otu and Oluwasegun (2018) examined the influence of print media organizations on Nigeria's national unity during the 2015 presidential elections. It adopts secondary sources for data collection, which include national newspapers (The Nation, Guardian, and Nigerian Tribune), journal articles and book publications. The main dataset contains 1,063 campaign related news and 297 campaign advertisements, rigorously cleaned and filtered to remove extra content in order to avoid complications for the sake of perspective and scope. The study discovers that the media hyped bickering of the already polarized and incongruous nation by disseminating 'fake news' and 'hate speeches'. In achieving democratization and national unity, the paper notes that fake news and hate speech must be countered and documented. It concludes that there must be more sense of professionalism among Nigerian journalists and media outlets, based on the principle of political-morality.

Ojebuyi and Salawu (2018) examined the level of objectivity demonstrated by Nigerian newspapers in their coverage of elections with specific reference to the Nigeria's 2015 presidential election. Textual analysis was used to examine news stories about electioneering activities of the two leading political parties, the People's Democratic Party (PDP) and the All Progressives Congress (APC), as reported by The Nation, Nigerian Tribune, The Punch and Vanguard newspapers, which were selected purposively based on their national reach and ownership. The newspapers fore-grounded some news stories about the political parties and their presidential candidates while they buried others in manners that reflected biases influenced by ownership and political alignments of the newspapers. This trend has implications for Nigeria's democracy as the frames adopted by the news media to report electioneering activities may determine the voting decisions of the electorate and the final outcome of elections. Therefore, Nigerian news media should be fair and objective while reporting sensitive issues such as elections.

Adegbola and Gearhart (2019) examined the relationship between media use and political engagement among Kenya, Nigeria and U.S.A. The current study expands this line of research using a secondary analysis of a worldwide survey $(\mathrm{N}=1,775)$ collected by Pew Research to examine antecedents of political engagement in three nations: the United States, Kenya, and Nigeria. This study examines country-specific differences in how views on national politics and media use differently relate to political engagement. Results identify differences in the effects of traditional and new media use on political engagement between countries. Specifically, accessing news from social media and online news platforms is related to higher levels of political participation across countries. However, the influence of positive perceptions of the economy on political participation is found to differ in each nation. Implications for research on media use and political behavior across countries varying in democratization are discussed.

Jatula and Lodge (2016) examined the political effect of regional concentration of newspaper production in Nigeria's multi-ethnic and multicultural society to investigate if regional media concentration has weakened, detracted or even strengthened the role newspapers play in the democratic process. Using focus group discussions and content analysis, the study found that the divergent political, economic and historical roots of the press in both news publishing hubs in Nigeria, embedded in the nation's peculiar cultural and political history have manifested in intense rivalry and power struggle between and among newspapers in the hubs. The study recommends the setup of an independent media watchdog, with powers to monitor and regulate inaccuracies and bias in news reporting.

Aghamelu (2013) examined the role of the mass media in Nigerian electoral process as it pertains to overall 
development of Nigeria. The objective of this paper is to readdress media practice in Nigeria to its fundamental ethical journalistic foundation as basis for positive contribution to national integration. It is also aimed at the examination of both external (official) and internal obstacles that hinder the realization of the goal. This paper uses the method of comparative phenomenological analysis to examine the performances of the media in Nigerian electoral process with regard to its fundamental roles to inform, educate, entertain and monitor in the electoral process. The study found that the mass media has significantly impacted on the electoral process in Nigeria, with results not conclusively negative or positive.

Ekeanyanwu (2011) evaluated Nigeria's press coverage of political crises and conflicts during the President Obasanjo (Second Term) regime of 2003-2007. The major focus of this paper is to assess the role of the Nigerian press in the struggle for political positions, which breeds crises and conflicts especially in a pluralistic society. It is the position of the paper that the Nigerian press has not fared very well in reporting political conflicts and crises because of the advocacy position adopted by most of them. It is also observed that editorial influence on the part of publishers may not be unconnected with this trend. Using the content analytical research method as the main instrument of data generation, this paper submits that the Nigerian press has operated more as active players in political crises and conflicts than as an impartial judge of such crises and conflicts. This has negatively affected the management of such crises and conflicts. The paper therefore cautions against advocacy journalism in the Nigerian media industry and suggests more public participation in the media industry through "people" ownership. The press should also strive towards better professional and ethical practices in the industry and ensures that it only engages in constructive and balanced reporting of conflicts and issues.

Bello, Yusuf, Yusuf and Akintola (2017) examined the impact of social media usage on political participation of university undergraduates for political stability in Nigeria. This study is a descriptive survey research. The population of this study consisted of all undergraduates in universities in Oyo State. The target population for this study was all 400 level undergraduates from two purposively sampled universities in Oyo State. The multi-stage sampling procedure was adopted for this study, as different sampling techniques were used at different stages of sampling in this study. Proportionate sampling technique was adopted in the selection of 387 respondents from the two sampled universities. A researchers'-designed questionnaire with psychometrics properties of content validity and 0.84 reliability index. Percentage, mean and standard deviation, and bar chart were used to illustrate the results. Results show, that social media is indispensable among university undergraduates and has a greater impact on their political participation in political stability. It shows that utilizing social media is an effective strategy for arousing the interest of university undergraduates in political participation. University undergraduates do not want social media to be regulated as it provides them with the tool to engage in governance and ensure the country remain politically stable. It also instituted the importance of a holistic approach to social media development, in terms of research and practice.

\subsection{Methodology}

The study based on the press and the political polarization of Nigeria National Development in, Enugu state. The total population for the study was four thousand, seven hundred and twenty six $(4,726)$ comprising civil servants, business men and women in Enugu metropolis. The study used the survey approach. The primary sources were personal interview and the administration of questionnaire to the traders. Out of a population of 4726 traders, the sample size of 472.6 was chosen after applying the 10 percent of the total population for the determination of adequate sample size. Out of 473 respondents of the sample size, 373 respondents returned the questionnaire and accurately filled. That gave 79 percent response rate. The validity of the instrument was tested using content analysis and the result was good. The reliability was tested using the Pearson correlation coefficient (r). It gave a reliability co-efficient of 0.78 which was also good. Data was presented and analyzed by mean score (3.0 and above agreed while below 3.0 disagreed) and standard deviation using Sprint Likert Scale. The hypotheses were analyzed using Z-test statistic tool.

\subsection{Data Presentation and Analyses}

Likert Scale Analyses

4.1 Research question one. To what extent does the Nigerian newspapers' headline affect the provision of unified quality education and skill development?

Table 4.1:Responses on the Nigerian newspapers' headline affect the provision of unified quality education and skill development.

\begin{tabular}{lllllllllll}
\hline & & $\mathbf{5}$ & $\mathbf{4}$ & $\mathbf{3}$ & $\mathbf{2}$ & $\mathbf{1}$ & $\sum \mathbf{F X}$ & - & SD & Decision \\
& & SA & $\mathbf{A}$ & $\mathbf{N}$ & $\mathbf{D A}$ & $\mathbf{S D}$ & & $\mathbf{X}$ & & \\
\hline 1 & The lead in the Nigeria & 100 & 784 & 147 & 146 & 35 & 1212 & 3.25 & 1.119 & Agree \\
& newspaper has disrupted & 20 & 196 & 49 & 73 & 35 & 373 & & & \\
& wellness activities of the & 5.4 & 52.5 & 13.1 & 19.6 & 9.4 & $100 \%$ & & &
\end{tabular}

people. 
2 The byline in the Nigeria papers thwarts the spirit of sports in Nigeria.

3 The caption of the 560 information about a paper affects the coming together for equal ongoing fitness.

4 The pull quote may disturb 830 the social growth of all 166 participants in the skill 44.5 development.

5 The intellectual The intellectual acquisition 66 of the people is hampered by 133 the drop head of newspaper.

Total grand mean and standard deviation

Source: Field Survey, 2020

Table 4.1, agreed that the lead in the Nigeria newspaper has disrupted wellness activities of the people with mean score of 3.25 and standard deviation of 1.119. The byline in the Nigeria papers thwarts the spirit of sports in Nigeria with mean score of 4.09 and standard deviation of 1.150. The caption of the information about a paper affects the coming together for equal ongoing fitness with mean score of 3.37 and standard deviation of 1.484. The pull quote may disturb the social growth of all participants in the skill development with mean score of 3.65 and standard deviation of 1.415 , the intellectual acquisition of the people is hampered by the drop head of newspaper with mean score of 4.13 and standard deviation of .906 .

\subsection{Research Question Two. What is the relationship between media contact and Programmatic and security} in Nigeria?

Table 4.2: Responses on the relationship between media contact and programmatic and security in Nigeria

\begin{tabular}{|c|c|c|c|c|c|c|c|c|c|c|}
\hline & & $\begin{array}{l}5 \\
\text { SA } \\
\end{array}$ & $\begin{array}{l}4 \\
\mathbf{A}\end{array}$ & $\begin{array}{l}\mathbf{3} \\
\mathbf{N} \\
\end{array}$ & $\begin{array}{l}2 \\
\mathbf{D A}\end{array}$ & $\begin{array}{l}1 \\
\text { SD }\end{array}$ & $\sum F X$ & $\overline{\mathbf{X}}$ & SD & Decision \\
\hline 6 & $\begin{array}{l}\text { The media being resourceful has } \\
\text { aided transparency in Nigeria. }\end{array}$ & $\begin{array}{l}1225 \\
245 \\
65.7\end{array}$ & $\begin{array}{l}336 \\
84 \\
22.5\end{array}$ & $\begin{array}{l}45 \\
15 \\
4.0\end{array}$ & $\begin{array}{l}24 \\
12 \\
3.2\end{array}$ & $\begin{array}{l}17 \\
17 \\
4.6\end{array}$ & $\begin{array}{l}1647 \\
373 \\
100 \%\end{array}$ & 4.42 & 1.033 & Agree \\
\hline 7 & $\begin{array}{l}\text { Building relationship through } \\
\text { media enhances a reputable } \\
\text { programmatic provider in } \\
\text { Nigeria }\end{array}$ & $\begin{array}{l}650 \\
130 \\
34.9\end{array}$ & $\begin{array}{l}392 \\
98 \\
26.3\end{array}$ & $\begin{array}{l}159 \\
53 \\
14.2\end{array}$ & $\begin{array}{l}52 \\
26 \\
7.0\end{array}$ & $\begin{array}{l}66 \\
66 \\
17.7\end{array}$ & $\begin{array}{l}1319 \\
373 \\
100 \%\end{array}$ & 3.54 & 1.467 & Agree \\
\hline 8 & $\begin{array}{l}\text { The effect of storytelling } \\
\text { through media gives the use of } \\
\text { insights to monitor campaign in } \\
\text { real time. }\end{array}$ & $\begin{array}{l}775 \\
155 \\
41.6\end{array}$ & $\begin{array}{l}428 \\
107 \\
28.7\end{array}$ & $\begin{array}{l}123 \\
41 \\
11.0\end{array}$ & $\begin{array}{l}100 \\
50 \\
13.4\end{array}$ & $\begin{array}{l}20 \\
20 \\
5.4\end{array}$ & $\begin{array}{l}1446 \\
373 \\
100 \%\end{array}$ & 3.88 & 1.238 & Agree \\
\hline 9 & $\begin{array}{l}\text { The listening of media makes } \\
\text { one to be proactive. }\end{array}$ & $\begin{array}{l}720 \\
144 \\
38.6\end{array}$ & $\begin{array}{l}476 \\
119 \\
31.9\end{array}$ & $\begin{array}{l}150 \\
50 \\
13.4\end{array}$ & $\begin{array}{l}60 \\
30 \\
8.0\end{array}$ & $\begin{array}{l}30 \\
30 \\
8.0\end{array}$ & $\begin{array}{l}1436 \\
373 \\
100 \%\end{array}$ & 3.85 & 1.244 & Agree \\
\hline 10 & $\begin{array}{l}\text { There is always a room to define } \\
\text { what brand safety means for } \\
\text { each person. }\end{array}$ & $\begin{array}{l}885 \\
177 \\
47.5\end{array}$ & $\begin{array}{l}460 \\
115 \\
30.8\end{array}$ & $\begin{array}{l}120 \\
40 \\
10.7\end{array}$ & $\begin{array}{l}40 \\
20 \\
5.4\end{array}$ & $\begin{array}{l}21 \\
21 \\
5.6\end{array}$ & $\begin{array}{l}1527 \\
373 \\
100 \%\end{array}$ & 4.09 & 1.139 & Agree \\
\hline & $\begin{array}{l}\text { Total grand mean and } \\
\text { standard deviation }\end{array}$ & & & & & & & 3.956 & 1.224 & \\
\hline
\end{tabular}

\section{Source: Field Survey, 2020}

Table 4.2, agreed that the media being resourceful has aided transparency in Nigeria with mean score of 4.42 and standard deviation of 1.033. Building relationship through media enhances a reputable programmatic provider in Nigeria with mean score of 3.54 and standard deviation of 1.467. The effect of storytelling through media gives the use of insights to monitor campaign in real time with mean score of 3.88 and standard deviation of 1.238 . The listening of media makes one to be proactive with mean score of 3.85 and standard deviation of 1.244 , There is always a room to define what brand safety means for each person with mean score of 4.09 and standard deviation 
of 1.139 .

4.3 Research Question Three. What is the relationship between contact information and provision of employment in Nigeria?

Table 4.3: Responses on the relationship between contact information and provision of employment in Nigeria

\begin{tabular}{|c|c|c|c|c|c|c|c|c|c|c|}
\hline & & $\begin{array}{ll}5 \\
\text { SA }\end{array}$ & $\begin{array}{l}4 \\
\mathbf{A}\end{array}$ & $\begin{array}{l}\mathbf{3} \\
\mathbf{N}\end{array}$ & $\begin{array}{l}\mathbf{2} \\
\text { DA }\end{array}$ & $\begin{array}{l}1 \\
\text { SD }\end{array}$ & $\sum \mathbf{F X}$ & $\overline{\mathrm{X}}$ & SD & Decision \\
\hline 11 & $\begin{array}{l}\text { The use of network aids in } \\
\text { declaring vacancy in positions in } \\
\text { Nigeria }\end{array}$ & $\begin{array}{l}965 \\
193 \\
51.7\end{array}$ & $\begin{array}{l}504 \\
126 \\
33.8\end{array}$ & $\begin{array}{l}66 \\
22 \\
5.9\end{array}$ & $\begin{array}{l}36 \\
18 \\
4.8\end{array}$ & $\begin{array}{l}14 \\
14 \\
3.8\end{array}$ & $\begin{array}{l}1585 \\
373 \\
100 \%\end{array}$ & 4.25 & 1.024 & Agree \\
\hline 12 & $\begin{array}{l}\text { The use of chat communicates } \\
\text { company specific job positions. }\end{array}$ & $\begin{array}{l}1030 \\
206 \\
55.2\end{array}$ & $\begin{array}{l}464 \\
116 \\
31.1\end{array}$ & $\begin{array}{l}42 \\
14 \\
3.8\end{array}$ & $\begin{array}{l}38 \\
19 \\
5.1\end{array}$ & $\begin{array}{l}18 \\
18 \\
4.8\end{array}$ & $\begin{array}{l}1592 \\
373 \\
100 \%\end{array}$ & 4.27 & 1.077 & Agree \\
\hline 13 & $\begin{array}{l}\text { Voice calls can describe the } \\
\text { length of job and duration of } \\
\text { schedule. }\end{array}$ & $\begin{array}{l}845 \\
169 \\
45.3\end{array}$ & $\begin{array}{l}572 \\
143 \\
38.3\end{array}$ & $\begin{array}{l}57 \\
19 \\
5.1\end{array}$ & $\begin{array}{l}44 \\
22 \\
5.9\end{array}$ & $\begin{array}{l}20 \\
20 \\
5.4\end{array}$ & $\begin{array}{l}1538 \\
373 \\
100 \%\end{array}$ & 4.12 & 1.100 & Agree \\
\hline 14 & $\begin{array}{l}\text { Portals presents work hours and } \\
\text { benefits }\end{array}$ & $\begin{array}{l}115 \\
23 \\
6.2\end{array}$ & $\begin{array}{l}920 \\
230 \\
61.7\end{array}$ & $\begin{array}{l}90 \\
30 \\
8.0\end{array}$ & $\begin{array}{l}106 \\
53 \\
14.2\end{array}$ & $\begin{array}{l}37 \\
37 \\
9.9\end{array}$ & $\begin{array}{l}1268 \\
373 \\
100 \%\end{array}$ & 3.40 & 1.116 & Agree \\
\hline 15 & $\begin{array}{l}\text { Messaging can describes the } \\
\text { nature of pay and anticipation. }\end{array}$ & $\begin{array}{l}760 \\
152 \\
40.8\end{array}$ & $\begin{array}{l}428 \\
107 \\
28.7\end{array}$ & $\begin{array}{l}132 \\
44 \\
11.8\end{array}$ & $\begin{array}{l}40 \\
20 \\
5.4\end{array}$ & $\begin{array}{l}50 \\
50 \\
13.4\end{array}$ & $\begin{array}{l}1410 \\
373 \\
100 \%\end{array}$ & 3.78 & 1.380 & Agree \\
\hline & $\begin{array}{l}\text { Total grand mean and } \\
\text { standard deviation }\end{array}$ & & & & & & & 3.964 & 1.139 & \\
\hline
\end{tabular}
Source: Field Survey, 2020

Table 4.3, agreed that the use of network aids in declaring vacancy in positions in Nigeria with mean score of 4.25 and standard deviation of 1.024. The use of chat communicates company specific job positions with mean score of 4.27 and standard deviation of 1.077. Voice calls can describe the length of job and duration of schedule with mean score of 4.12 and standard deviation of 1.100 . Portals presents work hours and benefits with mean score of 3.40 and standard deviation of 1.116, Messaging can describes the nature of pay and anticipation with mean score of 3.78 and standard deviation of 1.380 .

\subsection{Test of Hypotheses}

4.4.1 Test of Hypothesis One: Nigerian newspapers' headline has positive effect on the provision of unified quality education and skill development in Nigeria to an extent.

Table 4.4.1.1: $\quad Z$ - test on Nigerian newspapers' headline has positive effect on the provision of unified quality education and skill development in Nigeria to an extent.

\begin{tabular}{llc}
\hline & & $\begin{array}{l}\text { Nigerian newspapers' headline has } \\
\text { positive effect on the provision of } \\
\text { unified quality education and skill } \\
\text { development in Nigeria to an } \\
\text { extent. }\end{array}$ \\
\hline $\mathrm{N}$ & Mean & 373 \\
Normal Parameters & Std Deviation & 3.698 \\
Most Extreme & Absolute & 1.215 \\
Most Extreme & Positive & .278 \\
Differences & Negative & .184 \\
Kolmogorov-Smirnon Z & & -.278 \\
Asymp. Sig.(2-tailed) & & 5.380 \\
\hline
\end{tabular}

Asymp. Sig.(2-tailed)

a. Test distribution is Normal

b. Calculated from data

Decision Rule

If the calculated $\mathrm{Z}$-value is greater than the critical $\mathrm{Z}$-value (i.e $\mathrm{Z}_{\text {cal }}>\mathrm{Z}_{\text {critical }}$ ), reject the null hypothesis and accept 
the alternative hypothesis accordingly.

Result

With Kolmogorov-Smirnon $Z$ - value of 5.380 and on Asymp. Significance of 0.000 , the responses from the respondents as display in the table is normally distributed. This affirms that the assertion of the most of the respondents that Nigerian newspapers' headline has positive effect on the provision of unified quality education and skill development in Nigeria to an extent.

Decision

Furthermore, comparing the calculated Z-value of 5.380 against the critical Z-value of 1.96 (2-tailed test at $95 \%$ level of confidence) the null hypothesis were rejected. Thus the alternative hypothesis was accepted which states that Nigerian newspapers' headline has positive effect on the provision of unified quality education and skill development in Nigeria to an extent.

4.4.2 Test of Hypothesis Two: Media contact and programmatic safety and security in Nigeria are significantly related.

Table 4.4.2.1: $\mathrm{Z}$ - test on Media contact and programmatic safety and security in Nigeria are significantly related

\begin{tabular}{llc}
\hline & & $\begin{array}{c}\text { Media contact and programmatic safety and } \\
\text { security in Nigeria are significantly related }\end{array}$ \\
\hline $\mathrm{N}$ & & 373 \\
Normal Parameters & Mean & 3.956 \\
& Std Deviation & 1.224 \\
Most Extreme & Absolute & .273 \\
Most Extreme & Positive & .204 \\
Differences & Negative & -.273 \\
Kolmogorov-Smirnon Z & & 5.267 \\
Asymp. Sig.(2-tailed) & & .000 \\
\hline
\end{tabular}

\section{Decision Rule}

c. Test distribution is Normal

d. Calculated from data

If the calculated $\mathrm{Z}$-value is greater than the critical $\mathrm{Z}$-value (i.e $\mathrm{Z}_{\mathrm{cal}}>\mathrm{Z}_{\text {critical }}$ ), reject the null hypothesis and accept the alternative hypothesis accordingly.

Result

With Kolmogorov-Smirnon Z - value of 5.267 and on Asymp. Significance of 0.000 , the responses from the respondents as display in the table is normally distributed. This affirms that the assertion of the most of the respondents that Media contact and programmatic safety and security in Nigeria are significantly related.

Decision

Furthermore, comparing the calculated Z- value of 5.267 against the critical Z-value of 1.96 (2-tailed test at $95 \%$ level of confidence) the null hypothesis were rejected. Thus the alternative hypothesis was accepted which states that Media contact and programmatic safety and security in Nigeria are significantly related.

4.4.3 Test of Hypothesis Three: Contact information and provision of employment in Nigeria are significantly related.

Table 4.4.3.1: $\mathrm{Z}$ - test on Contact information and provision of employment in Nigeria are significantly related

\begin{tabular}{llc}
\hline & & $\begin{array}{c}\text { Contact information and provision of } \\
\text { employment in Nigeria are significantly related. }\end{array}$ \\
\hline $\mathrm{N}$ & & 373 \\
Normal Parameters & Mean & 3.964 \\
& Std Deviation & 1.139 \\
Most Extreme & Absolute & .305 \\
Most Extreme & Positive & .223 \\
Differences & Negative & -.305 \\
Kolmogorov-Smirnon Z & & 5.88 \\
Asymp. Sig.(2-tailed) & & .000 \\
\hline
\end{tabular}

e. Test distribution is Normal

f. Calculated from data

Decision Rule

If the calculated $\mathrm{Z}$-value is greater than the critical $\mathrm{Z}$-value (i.e $\mathrm{Z}_{\mathrm{cal}}>\mathrm{Z}_{\text {critical }}$ ), reject the null hypothesis and accept the alternative hypothesis accordingly.

Result

With Kolmogorov-Smirnon Z - value of 5.88 and on Asymp. Significance of 0.000 , the responses from the 
respondents as display in the table is normally distributed. This affirms that the assertion of the most of the respondents that Contact information and provision of employment in Nigeria are significantly related.

\section{Decision}

Furthermore, comparing the calculated Z-value of 5.88 against the critical Z-value of 1.96 (2-tailed test at $95 \%$ level of confidence) the null hypothesis were rejected. Thus the alternative hypothesis was accepted which states that Contact information and provision of employment in Nigeria are significantly related.

\subsection{Discussion of Findings}

From the result of hypothesis one, comparing the calculated Z-value of 5.380 against the critical Z- value of 1.96 (2-tailed test at $95 \%$ level of confidence) the null hypothesis were rejected. Thus the alternative hypothesis was accepted which states that Nigerian newspapers' headline has positive effect on the provision of unified quality education and skill development in Nigeria to an extent. In support of the above result in the literature review, Eze, (2009) states that features that make up quality education include, quality learners, quality learning environment and quality content. Skills development is the process of identifying your skill gaps, and developing and honing these skills. From the result of hypothesis two, comparing the calculated Z- value of 5.267 against the critical Zvalue of 1.96 (2-tailed test at 95\% level of confidence) the null hypothesis were rejected. Thus the alternative hypothesis was accepted which states that Media contact and programmatic safety and security in Nigeria are significantly related. In support of the above result in the literature review, Aleyomi, Ajakaiye, Otu and Oluwasegun (2018) concludes that there must be more sense of professionalism among Nigerian journalists and media outlets, based on the principle of political-morality. From the result of hypothesis three, comparing the calculated Z- value of 5.88 against the critical Z- value of 1.96 (2-tailed test at $95 \%$ level of confidence) the null hypothesis were rejected. Thus the alternative hypothesis was accepted which states that Contact information and provision of employment in Nigeria are significantly related. In support of the above result in the literature review, Jatula and Lodge (2016) found that the divergent political, economic and historical roots of the press in both news publishing hubs in Nigeria, embedded in the nation's peculiar cultural and political history have manifested in intense rivalry and power struggle between and among newspapers in the hubs.

\subsection{Conclusion}

The study concluded that there is a relationship between media contact, contact information and provision of employment, programmatic safety and security and that the Nigerian newspapers' headlines has affect on the provision of unified quality education and skill development in Nigeria. The press has the role of providing information and reports to the general public in countries like Nigeria. The media help in the supply of the required political information that electorates would base their decision. Political polarization embodies the tension of its binary political ideologies and partisan identities. National development is the overall development or a collective socio-economic, political as well as religious advancement of a country or nation.

\subsection{Recommendation}

Based on the findings of the study the following recommendations were made:

i. The Nigerian newspapers' headline should be guided properly to avoid jeopardizing with the intellectual acquisition of the people.

ii. Media contact should be transparent enough for provision of reputable programmatic in Nigeria.

iii. There should be the provision of eligible personnel to man the employment information contact for clarity of job description and specification.

\section{References}

Adegbola, O. and Gearhart, S. (2019) Examining the relationship between media use and political engagement: A comparative study among the United States, Kenya and Nigeria. International Journal of Communication, 13

Aleyomi, M. B., Ajakaiye, O., Otu, o. A. and Oluwasegun, P. (2018) Mass media and political campaigns during the Nigerian 2015 presidential elections. Journal of Communication and Media Research, (10) 2

Bafumi, Joseph; Shapiro, Robert Y. (27 January 2009). "A New Partisan Voter" (PDF). The Journal of Politics. $71(1)$

Baldassarri, D. and Gelman, A. (2008). Partisans without Constraint: Political Polarization and Trends in American Public Opinion. American Journal of Sociology, 114 (2)

Bandura, Albert (1994). "Social cognitive theory and exercise of control over HIV infection". Preventing AIDS: $25-59$.

Baran, Stanley J.; Davis, Dennis K. (2009). Mass communication theory : foundations, ferment, and future (6th ed.). Boston, MA: Wadsworth. p. 416. ISBN 978-0495898870. Retrieved 18 October

Bello, M. B., Yusuf, H. T., Yusuf, A. and Akintola, M. (2017) Social media usage and political participation among iniversity undergraduates for political stability in Nigeria. Sarejevo Journal of Social Sciences, (8)1 
Carmines, E. G.; Ensley, M.J.; Wagner, M.W. (23 October 2012). "Who Fits the Left-Right Divide? Partisan Polarization in the American Electorate". American Behavioral Scientist. 56 (12): 1631-1653.

Ekeanyanwu, N. T. (2011) The Nigerian press coverage of political conflicts in a pluralistic society. Retrieved on 12th March, 2020 from https://www.researchgate.net/publication/272775429 The Nigerian press coverage of political conflicts in a pluralistic society

Eze, G.N. (2009) Features of quality education. Retrieved from https://www.researchgate.net/publication/317570906_FEATURES_OF_QUALITY_EDUCATION

Gusfield, J. R. (1994). The reflexivity of social movements: Collective be havior and mass society theory revisited (1 ed.). Philadelphia: Temple University Press.

Jatula, V. and Lodge, T. (2016) Media concentration and its effects on politics in Nigeria. African Journal of Media and Communication Studies, (2)1

Kadiri, K., Muhammed, Y. A., Raji, A. and Sulaiman, A. (2015) Mass media for sustainable democracy and development in Nigeria. Journal of Sustainable Development in Africa, Vol. 17, No. 2

Kellner, D. (2004). The Media and Democracy. Cambridge: Polity Press

Lawal, T. and Oluwatoyin, A. National development in Nigeria: Issues, challenges and prospects. Journal of Public Administration and Policy Research, Vol. 3, Issue 9.

Mass media", Oxford English Dictionary, online version November 2010

McQuail, Denis (2010). Mass communication theory: an introduction. London: SAGE Publications. pp. 420-430. ISBN 978-1849202923.

Ojebuyi, B. R. and Salawu, A. (2018) Partisanship and selective reporting in Nigerian newspapers' coverage of elections. African Renaissance, Vol. 15, No. 4.

Rao, M.S. (2010). Soft Skills - Enhancing Employability: Connecting Campus with Corporate. New Delhi: I. K. International Publishing House Pvt Ltd. p. 225.

Sanusi, S.L. (2012), "Nigeria's Economic Development Aspirations and theLeadership Question: Is There a Nexus?" Being a Text Delivered at the 2nd General (Dr) Yakubu Gowon Distinguished Annual Lecture Held on Friday, October 19.

Severin, Werner; Tankard, James (1997). Communication Theories: Origins, Methods, and Uses in the Mass Media. Longman. ISBN 978-0801317033

Stajkovic, A., and Luthans, F. (2003). "Social Cognitive Theory and Self-Efficacy: Implication for Motivation Theory and Practice." Motivation and Work Behavior, by Lyman W. Porter et al., McGraw-Hill/Irwin, 2003, pp. 126-139. 